\title{
"Retraction: The effect of human capital on performance of East African commercial banks"
}

\begin{tabular}{|c|c|}
\hline AUTHORS & $\begin{array}{l}\text { Muhammad Zia Aftab Khan (D http://orcid.org/0000-0003-2926-3229 } \\
\text { Ji Hyun Park (D) http://orcid.org/0000-0001-7691-6881 }\end{array}$ \\
\hline ARTICLE INFO & $\begin{array}{l}\text { Muhammad Zia Aftab Khan and Ji Hyun Park (2020). Retraction: The effect of } \\
\text { human capital on performance of East African commercial banks. Banks and } \\
\text { Bank Systems, 15(2), 56-66. doi:10.21511/bbs.15(2).2020.06 }\end{array}$ \\
\hline DOI & http://dx.doi.org/10.21511/bbs.15(2).2020.06 \\
\hline RELEASED ON & Tuesday, 28 April 2020 \\
\hline RECEIVED ON & Wednesday, 11 September 2019 \\
\hline ACCEPTED ON & Wednesday, 26 February 2020 \\
\hline LICENSE & $\begin{array}{l}(\text { (c) } \text { EY } \\
\text { This work is licensed under a Creative Commons Attribution } 4.0 \text { International } \\
\text { License }\end{array}$ \\
\hline JOURNAL & "Banks and Bank Systems" \\
\hline ISSN PRINT & $1816-7403$ \\
\hline ISSN ONLINE & $1991-7074$ \\
\hline PUBLISHER & LLC "Consulting Publishing Company "Business Perspectives" \\
\hline FOUNDER & LLC "Consulting Publishing Company "Business Perspectives" \\
\hline$\sigma^{0}$ & $\begin{array}{l}\text { ニ:ニ } \\
\text { 三: }\end{array}$ \\
\hline NUMBER OF REFERENCES & NUMBER OF FIGURES \\
\hline 100 & 0 \\
\hline
\end{tabular}

(c) The author(s) 2021. This publication is an open access article. 


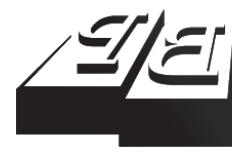

\section{BUSINESS PERSPECTIVES}

LLC "CPC "Business Perspectives" Hryhorii Skovoroda lane, 10, Sumy, 40022, Ukraine www.businessperspectives.org
Received on: $11^{\text {th }}$ of September, 2019 Accepted on: $26^{\text {th }}$ of February, 2020 Published on: $28^{\text {th }}$ of April, 2020
( $)$ Muhammad Zia Aftab Khan, Ji Hyun Park, 2020

Muhammad Zia Aftab Khan, Ph.D. Professor, Youngsan University of South Korea, South Korea.

Ji Hyun Park, Ph.D., Professor, Law Faculty, Youngsan University of South Korea, South Korea.

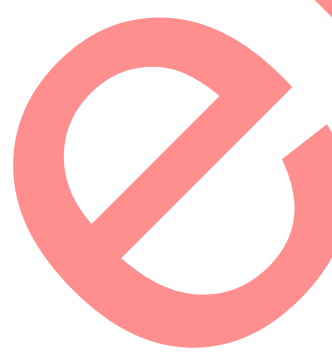

This is an Open Access article distributed under the terms of the Creative Commons Attribution 4.0 International license, which permits unrestricted re-use, distribution, and reproduction in any medium, provided the original work is properly cited.

Conflict of interest statement: Author(s) reported no conflict of interest

\section{THE EFFECT OF HUMAN CAPITAL ON PERFORMANCE OF EAST AFRICAN COMMERCIAL BANKS}

\section{Abstract}

This paper aims to examine the effect of human capital on performance of East African commercial banks. Given increased competition and regulatory pressure, commercial banks must understand the intrinsic value of human capital as a key success factor.

With extraordinary growth in financial innovations, firms are gradually focusing on knowledge resources as a source of competitive advantage and superior performance. Human capital lies at the heart of knowledge resources. Therefore, firms should strive to develop and use human capital for sustained superior performance. The study population consists of 42 commercial banks licensed by the Central Banks of East Africa. Data was analyzed using descriptive and inferential statistics. The study had three control variables such as firm size, firm age, and market share. The independent effect of human capital on firm performance was examined. Thus, this study is more objective and superior. It is focused on the East African banking sector. Therefore, future research should consider other sectors of the economy. Besides, all the variables were measured quantitatively, which allowed considering the use of qualitative measures. This can shed more light on the human capital and performance nexus. The results of the study are of strategic importance to managers and regulators, given the important link between banks and macroeconomic factors. Accordingly, these findings will help develop strategic decisions and policies that support the growth of a robust African banking sector.

\section{Keywords}

banking sector, market share, economic control, regulatory pressure

JEL Classification

G10, G17, G 21

\section{INTRODUCTION}

Researchers claim that the world's economies are gradually moving from being production-based to knowledge-based due to technological revolutions and changing customer expectations (Clarke \& Gholamshahi, 2018; Mahdi, Nassar, \& Almsafir, 2019). Accordingly, modern-day firms must appreciate the importance of intangible resources as a source of competitive advantage and superior performance. As early as in the 1960s, Becker (1964) mentioned that physical factors of production explained a relatively small part of the growth in income and wealth of nations. Later in the 1990s, Drucker (1993) stated that traditional factors of production were easily accessible to competitors and had little strategic importance, which emphasized the importance of intangible resources. Becker (2009) observed that human capital accounted for approximately three-quarters of the developed countries' wealth. From the same point of view, it is believed that human capital affects the development and utilization of other knowledge resources of a firm (Wang \& Chang, 2005; Shivdas \& Ray, 2017).

The influence of knowledge resources on firm performance is widely cited in the extant literature. However, the impact differs across indus- 
tries due to heterogeneity of business processes and resource profiles (Seleim, Ashour, \& Bontis, 2007; Megna \& Mueller, 1991). In particular, human capital is vital to service industries, for instance, banks, where competitive advantage hinges on innovation and service quality (Young, Su, S.-C. Fang, \& S.-R. Fang, 2009). Furthermore, banks maintain minimal physical assets, so they are more reliant on human capital for competitive advantage. Accordingly, banks must invest heavily in their human capital for long-term sustainability (Noe, Hollenbeck, Gerhart, \& Wright, 2017; Chicu, del Mar Pàmies, Ryan, \& Cross, 2019; Gabriel, 2016; Chen \& Huang, 2009).

Despite the importance of human capital to service organizations, only a few studies have examined the effect of human capital on firm performance in the banking sector, in particular, in East Africa, which pioneered mobile banking. Most of the mentioned studies focused on manufacturing firms in developed and emerging economies, that is, the U.S., Europe, Canada, and Asia. In addition, most of previous studies measured human capital using qualitative measures (Khalique, Bontis, Nassir bin Shaari, \& Md. Isa, 2015; Bapna, Langer, Mehra, Gopal, \& Gupta, 2014;). Therefore, the main focus of the study is to examine the effect of human capital on the performance of Kenyan banks.

\section{LITERATURE REVIEW AND HYPOTHESES DEVELOPMENT}

Resource-based view theory suggests that firm resources are a source of competitive advantage and superior performance (Hatch \& Dyer, 2004). Strategic resources are characterized as valuable, rare, imperfectly imitable and non-substitutable (Barney, 1986; Penrose, 1959; Peteraf, 1993; Wernerfelt, 1984; Maditinos, Chatzoudes, Tsairidis, \& Theriou, 2011). In an era of knowledge, intangible resources are considered more important than tangible resources (Clarke \& Gholamshahi, 2018; Mahdi, Nassar, \& Almsafir, 2019). This view is corroborated by Itami and Roehl (1987), who stated that "intangible assets, such as a particular technology, accumulated consumer information, brand name, reputation, and corporate culture, are invaluable to the firm's competitive power. In fact, these invisible assets are often the only real source of competitive edge that can be sustained over time." A collective term for intangible resources is intellectual capital (Attar, Kang, \& Sohaib, 2019). According to Stewart (1997), intellectual capital refers to intellectual material, information, knowledge, intellectual property, experience, and relationships that are used for a company's success. Intellectual capital consists of human capital, structural capital and customer (relational) capital (Edvinsson \& Malone, 1997). With respect to intellectual capital, there is a universal consensus among researchers that human capital has the most pronounced influence on performance (Hall, 1992).

\subsection{Human capital}

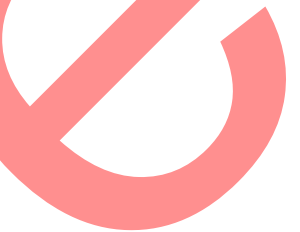

In the field of management, human capital has received considerable research attention (Sahari, Nichol, \& Yusof, 2019; Ulrich \& Kryscynski, 2019). Srivastava (2001) claims that "the power and product of the human mind is the supreme source of competitive advantage in an era of knowledge economies". In addition, some studies claim that human capital supports the development and application of all forms of organizational knowledge (Wang \& Chang, 2005; Benhabib \& Spiegel, 2005). Likewise, Bontis, Ciambotti, Palazzi, and Sgro (2018) and Bratianu (2018) postulate that human capital nurtures other forms of organizational knowledge, while Jin. Han, Jia. Han, and Brass (2014) claim that human capital drives innovativeness and complements other elements of intellectual capital. The superiority of human capital is attributable to its flexibility, adaptability, and self-regeneration.

Extant literature shows diverse definitions of human capital. Halim (2010) views human capital as "what a single employee brings into value-adding processes, consisting of professional competence, social competence, employee motivation, and leadership ability". Sveiby (1997) asserts that human capital is the capacity of employees to act in varied situations in a manner that creates both tangible and intangible assets. Additionally, Schultz (1961) avers that human capital consists of knowledge, skills, and abilities of an organization's workforce. Toms, Wilson, and Wright (2013) define human capital as people, their abilities and performance in an organization. Reichenberg 
and Andreassen (2018) view human capital as "the qualities of the individuals, their qualifications and competencies". Davenport and Prusak (1998) contend that human capital embodies intangible resources of abilities, effort, and time that workers bring and invest in their work. In general terms, human capital symbolizes an organization's collection of employees' skills, abilities, attitudes, and experiences that create and deliver value.

Generally, it is believed that human beings possess certain abilities, knowledge, skills, and expertise, which organizations and nations can leverage for competitive advantage and ultimately optimize goals (Bapna, Langer, Mehra, Gopal, \& Gupta, 2013). Some of these goals include regional balance and economic growth (Fleisher, Li, \& Zhao, 2010), firm growth (Colombo \& Grilli, 2005), regional productivity (Gennaioli, La Porta, Lopezde-Silanes, \& Shleifer, 2013), foreign direct investment flow (Noorbakhsh, Paloni, \& Youssef, 2001), financial performance (Crook, Todd, Combs, Woehr, \& Ketchen, 2011), innovation (Dakhli \& De Clercq, 2007), technology diffusion (Benhabib \& Spiegel, 2005; Link \& Siegel, 2007), entrepreneurial success (Martin, McNally, \& Kay, 2013) and employees earnings (Harris \& Helfat, 1997).

Despite the importance attached to human capital, its influence on firm performance is largely controversial. A number studies indicate positive causality (Crook, Todd, Combs, Woehr, \& Ketchen, 2011; Seleim, Ashour, \& Bontis, 2007; Shrader \& Siegel, 2007), while others suggest a negative association (Smriti \& Das, 2017; Kor \& Mahoney, 2005; Firer \&Williams, 2003). Still, Khalique, Bontis, Nassir bin Shaari, and Md. Isa (2015) asserted that human capital had no effect on firm performance, while Wang and Chang (2005) found an indirect effect through the other three sub-constructs of intellectual capital (process capital, innovation capital and customer capital). Evidently, the relationship between human capital and firm performance requires further inquiry.

\subsection{Performance of the banking sector}

The banking sector is of enormous importance to regulators, scholars, and practitioners due to its influence on economic development.
Research shows that banks have an influence on economic growth (Tongurai \& Vithessonthi, 2018; Balcilar, Gupta, Lee, \& OlasehindeWilliams, 2018), job creation (Toms, Wilson, \& Wright, 2019; Cai, Song, Ma, Dong, \& Xu, 2018; Khan \& Anuar, 2018), resource allocation (Beck, Demirgüç-Kunt, \& Levine, 2007; Dywer, 2018), poverty alleviation (Abdin, 2016; Sikod \& Baye, 2015), education (Sun \& Yannelis, 2016; Goksu \& Goksu, 2015), and agriculture (Anetor, Ogbechie, Kelikume, \& Ikpesu, 2016). Consequently, an underperforming banking sector undermines economic growth through reduced investments in the production of goods and services (Sufian \& Chong, 2008; Dietrich \& Wanzenried, 2014). Despite the importance attached to the banking sector, studies show that the sector continues to grapple with numerous challenges ranging from swelling non-performing loans, stringent regulations and technological revolution, which have adversely affected performance (Gololo, 2018, Psillaki \& Mamatzakis, 2017). Given the aforesaid challenges, the East African banking sector is regarded as one of the most innovative, vibrant and resilient in Africa, which demonstrates the importance of intellectual capital as postulated by the resource-based view (Kasekende \& Nikolaidou, 2018; Muthinja \& Chipeta, 2018; Carletti, Senbet, Cull, Allen, Qian, \& Valenzuela, 2018). Meanwhile, the current debate among researchers reveals elements of intellectual capital that have a significant influence on firm performance (Link \& Siegel, 2007; Wang \& Chang, 2005; Reinartz, Krafft, \& Hoyer, 2004). Previous studies have singled out human capital as the main sub-construct of intellectual capital due to its effect on other sub-constructs and its simultaneous effect on various organization outcomes (Crook, Todd, Combs, Woehr, \& Ketchen, 2011; McDowell, Peake, Coder, \& Harris, 2018; Benevene, Kong, Lucchesi, \& Cortini, 2019). In view of the aforesaid, this study postulates that human capital has an impact on firm performance and the hypotheses are formulated as follows:

H0: Human capital has no significant effect on firm performance.

H1: Human capital has a significant effect on firm performance. 


\section{RESEARCH DATA AND METHODOLOGY}

\subsection{Sample and data}

This study was grounded on the positivist paradigm that postulates that experimental observation and reason based on experience are the basis for understanding human behavior. The study is longitudinal and explanatory. The population consisted of all 42 commercial banks licensed by the Central Bank of Kenya. However, only 31 banks qualified for analysis due to missing data. Data was extracted from banks' annual reports and the Central Bank of Kenya supervisory reports for 2008-2017, which yielded 310 observations. The data was analyzed through descriptive and inferential statistics. Specifically, the data was summarized using descriptive statistics, while pairwise correlation analysis was applied to ascertain the nature and strength of relationships between the research variables. The hypotheses were tested through multiple regression analysis

\subsection{Measurement of variables}

The study took into account four types of variables: an independent variable (human capital), control variables (firm size, firm age, and firm market share) and a dependent variable (performance). Firm performance was measured as return on assets (ROA). A high ROA implies that a firm was utilizing its assets efficiently and for value. Human capital was the explanatory variable, and the proxy was measured as the average employee compensation (staff costs per employee). This study used staff costs per employee as a proxy of human capital. Staff costs comprise of salaries, wages, training costs, pension and other employee benefits (Pulic, 2000; P. Ståhle, S. Ståhle, \& Aho, 2011). Staff costs per employee are justified for three reasons. First, from a strategic point of view, staff costs are not expenses, rather they are investment, since human capital plays a critical role in value creation (Young, Su, S.-C. Fang, \& S.-R. Fang, 2009; Edvinsson \& Malone, 1997; Pulic, 2000; Pucar, 2012; Al-Musali \& Ku Ismail, 2016). Second, staff costs per employee indicate the quality of a firm's human resources (Hahn, 2009). Firms rarely disclose employees' level of education and annual investment on human capital development in their annual fi- nancial reports implying that such information is the domain of primary data, which is not as objective as secondary data. To control for sample heterogeneity, the study controlled for the firm and industry factors by incorporating firm size, firm age, and market share. Firm age was measured as the number of years since the commencement of operations (Ilaboya \& Ohiokha, 2016). Firm size was measured as the logarithm of total assets (Wan \& Zhang, 2018; Chiorazzo, Milani, \& Salvini, 2008). Data on market share was extracted from the Central Bank of Kenya annual supervisory reports. Market share is a composite index of net assets, deposits, total shareholder funds, number of loan accounts and number of deposit accounts. The regression model is illustrated as follows:

$$
\begin{aligned}
& F P_{i t}=\beta_{0}+\beta_{1} H C_{i t}+\beta_{2} F A_{i t}+ \\
& +\beta_{3} F S_{i t}+\beta_{4} M S_{i t}+\varepsilon_{i t},
\end{aligned}
$$

where $F P$ - firm performance; $H C$ - human capital; $F A$ - firm age; $F S$ - firm size; $M S$ - market share; and $\varepsilon_{i t}$ - error term.

\section{RESULTS AND ANALYSIS}

The study conducted a variety of diagnostic tests to determine the appropriateness of the panel data for analysis. The tests included normality, stationarity, multicollinearity, and autocorrelation. All the tests established that the data was suitable for further statistical analysis. Descriptive statistics are presented in Table 1, results of correlation analysis in Table 2 and the results of multiple regression analysis in Table 3.

Table 1 shows that the average bank performance for 2008-2017 was 3\%. In addition, the average bank age was 35 years, while the mean bank size stood at Ksh 76.6 billion. Further, the table indicates that the mean human capital was 2,079.328, while the average bank market share was 3.09\%.

Table 2 shows that all the variables were positively correlated as evidenced by human capital and performance $(r=0.598, \rho<0.01)$, firm age and performance $(r=0.294, \rho<0.01)$, firm size and performance $(r=0.372, \rho<0.01)$, market share and firm performance $(r=0.713, \rho<0.01)$, firm size and firm age $(r=0.542, \rho<0.01)$, firm size and hu- 
Table 1. Descriptive statistics of the research variables

Source: Compiled by authors (2019).

\begin{tabular}{|c|c|c|c|c|c|}
\hline Variable & Obs. & Mean & Min & Max & Std. dev \\
\hline Firm Performance & 310 & 0.03 & 0.00 & 0.10 & 0.018354 \\
\hline Human Capital & 310 & $2,079.328$ & 845.8718 & $3,930.5$ & 687.6502 \\
\hline Bank Size & 310 & $76,600,000,000$ & $2,289,000,000$ & $556,000,000,000$ & $96,200,000,0$ \\
\hline Bank Age & 310 & 34.82 & 1.00 & 121.00 & 29.22061 \\
\hline Market Share & 310 & 3.09 & 0 & 20.62 & 4.603822 \\
\hline
\end{tabular}

Table 2. Results of pairwise correlation analysis

Source: Compiled by authors (2019).

\begin{tabular}{l|c|c|c|c}
\hline \multicolumn{1}{c|}{ Variable } & FP & HC & BA & BS \\
\hline Firm Performance (FP) & 1 & - & - & - \\
\hline Huma Capital (HC) & $.598^{* *}$ & 1 & - & 1 \\
\hline Bank Age (BA) & $.294^{* *}$ & $.350^{* *}$ & $.542^{* *}$ & - \\
Bank Size (BS) & $.372^{* *}$ & $.231^{* *}$ & $.503^{* *}$ & $.808^{* *}$ \\
Market Share (MS) & $.713^{* *}$ & $.406^{* *}$ & 1 \\
\hline
\end{tabular}

Note: ${ }^{* *}$ correlation is significant at the 0.01 level (2-tailed); * correlation is significant at the 0.05 level (2-tailed).

Table 3. Correlation analysis results

Source: Compiled by authors (2019).

\begin{tabular}{|c|c|c|c|c|}
\hline Variable & Coefficient & Std. error & t-statistic & Prob. \\
\hline Constant & -1.818357 & 0.439151 & -4.140618 & 0.0000 \\
\hline Human Capital & 0.446711 & 0.047412 & 9.421881 & 0.0000 \\
\hline Bank Age & -0.086684 & 0.116672 & -0.742974 & 0.4581 \\
\hline Bank Size & -0.140683 & 0.069396 & -2.027238 & 0.0436 \\
\hline Market Share & 0.493777 & 0.037968 & 13.00524 & 0.0000 \\
\hline R-squared & 0.804278 & - & - & - \\
\hline F-statistic & 33.23696 & - & - & - \\
\hline Prob. (F-statistic) & 0.000000 & - & - & - \\
\hline Number of observations & 310 & - & - & - \\
\hline
\end{tabular}

man capital $(r=0.306, \rho<0.01)$, human capital and firm age $(r=0.447, \rho<0.01)$, market share and human capital $(r=0.406, \rho<0.01)$, market share and firm size $(r=0.808, \rho<0.01)$ and market share and firm age $(r=0.503, \rho<0.01)$.

Table 3 shows the results of the random effect regression analysis. The study found that human capital had a positive and significant effect on performance $(\boldsymbol{\beta}=0.447, \boldsymbol{\rho}<0.05)$. Thus, the null hypothesis that human capital has no significant effect on performance is rejected, and it is concluded that human capital had a positive and significant impact on bank performance. A one-percent change in human capital leads to a $44.7 \%$ change in firm performance. The study controlled for firm age, firm size and market share. Firm age $(\boldsymbol{\beta}=-0.0866$, $\boldsymbol{\rho}>0.05)$ and firm size $(\boldsymbol{\beta}=-0.1406, \boldsymbol{\rho}<0.05)$ had a negative effect on firm performance, while the impact of market share was positive and significant $(\boldsymbol{\beta}=0.494, \boldsymbol{\rho}<0.05)$. As firms grow in size, they suffer bureaucracies that lead to inefficiencies and resistance to change ultimately weakening performance. This phenomenon is christened as structural inertia (Hannan \& Freeman, 1984).

\section{DISCUSSION}

These findings support a resource-based view theory that postulates that competitive advantage and superior performance emanate from 
firm resource profile, in particular, intangible assets. The results are corroborated by Crook, Todd, Combs, Woehr, and Ketchen (2011), Felício, Couto, and Caiado (2014) and Bae and Lawler (2000). However, they contradict those of Wright, McCormick, Sherman, and McMahan (1999), who content human capital has no effect on performance, and those of Firer and Williams (2003), Hitt, Bierman, Shimizu, and
Kochhar (2001) and Kor and Mahoney (2005), who reported a negative association. The variation in findings can be due to contextual issues and industry factors. The mentioned studies focused on manufacturing firms in industrialized and developing economies, where structural capital is more important than human capital. Conversely, this study centered on the service industry, and a developing country.

\section{CONCLUSION}

The study sought to investigate the relationship between human capital and firm performance in the banking sector. Empirically, the study found that human capital had a positive and significant effect on firm performance, thus validating the propositions of a resource-based view theory. Banks operate in a highly competitive environment coupled with unprecedented growth in financial innovation and regulatory surveillance. Thus, banking institutions must invest heavily in their human capital for innovativeness and customer satisfaction to create sustained competitive advantage for survival and enhanced performance. This entails the use of human capital and other knowledge assets to solve customer problems in order to gain a competitive advantage. Furthermore, investments in recruitment, training, and retention of employees contribute to longterm value creation. For managerial purposes, bank managers should consider innovative ways of developing and utilizing their human capital to optimize firm performance. Despite the novelty of the findings, there are some limitations. First, the study was longitudinal, so the data was secondary and quantitative. Besides, all yariables were measured using proxies derived from income statements and balance sheets. Future studies may consider a qualitative approach. Finally, the paper focused on the Kenyan banking sector, so other sectors of the economy may be considered in future studies.

\section{ACKNOWLEDGMENT}

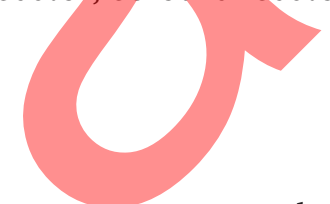

This work was supported by the Youngsan University Research Fund of 2020.

\section{AUTHOR CONTRIBUTIONS:}

Conceptualization: Muhammad Zia Aftab Khan, Ji Hyun Park.

Data curation: Muhammad Zia Aftab Khan, Ji Hyun Park.

Formal analysis: Muhammad Zia Aftab Khan, Ji Hyun Park.

Funding acquisition: Muhammad Zia Aftab Khan, Ji Hyun Park.

Investigation: Muhammad Zia Aftab Khan, Ji Hyun Park.

Methodology: Muhammad Zia Aftab Khan, Ji Hyun Park.

Project administration: Ji Hyun Park.

Resources: Muhammad Zia Aftab Khan.

Software: Muhammad Zia Aftab Khan, Ji Hyun Park.

Supervision: Muhammad Zia Aftab Khan.

Validation: Muhammad Zia Aftab Khan, Ji Hyun Park.

Visualization: Muhammad Zia Aftab Khan, Ji Hyun Park.

Writing - original draft: Muhammad Zia Aftab Khan, Ji Hyun Park.

Writing - reviewing \& editing: Muhammad Zia Aftab Khan, Ji Hyun Park. 


\section{REFERENCES}

1. Abdin, J. (2016). Financial development and poverty reduction: Exploring the links between the issues using evidence from Bangladesh. International Journal of Financial Research, 7(4), 44-65. https://doi.org/10.5430/ijfr. v7n4p44

2. Abhayawansa, S., Aleksanyan, M., \& Cuganesan, S. (2018). Conceptualization of intellectual capital in analysts' narratives: a performative view. Accounting, Auditing \& Accountability Journal, 31(3), 950-969. https://doi. org/10.1108/AAAJ-03-2017-2873

3. Abualoush, S., Masa'deh, R. E., Bataineh, K., \& Alrowwad, A. (2018). The role of knowledge management process and intellectual capital as intermediary variables between knowledge management infrastructure and organization performance. Interdisciplinary Journal of Information, Knowledge, and Management, 13, 279-309. https:// doi.org/10.28945/4088

4. Al-Musali, M. A., \& Ku Ismail, K. N. I. (2016). A cross-country comparison of intellectual capital performance and its impact on financial performance of commercial banks in GCC countries. International Journal of Islamic and Middle Eastern Finance and Management, 9(4), 512-531. https://doi.org/10.1108/ IMEFM-03-2015-0029

5. Anetor, F., Ogbechie, C., Kelikume, I., \& Ikpesu, F. (2016) Credit supply and agricultural production in Nigeria: a vector autoregressive (VAR) approach. Journal of Economics and Sustainable Development, 7(2), 131-143. Retrieved from https:// www.iiste.org/Journals/index.php/ JEDS/article/view/28449/29191

Ashour, A. S. (2000, April). Knowledge capital management. Reinventing management paradigm in the 21 st century. In Proceedings of the 12th International Conference on Training and Management Development Towards Arab Learning Organization (pp. 25-27).
7. Attar, M., Kang, K., \& Sohaib, O. (2019). Knowledge Sharing Practices, Intellectual Capital and Organizational Performance. In Proceedings of the 52nd Hawaii International Conference on System Sciences.

8. Bae, J., \& Lawler, J. J. (2000). Organizational and HRM strategies in Korea: Impact on firm performance in an emerging economy. Academy of Management Journal, 43(3), 502-517. https://doi. org/10.5465/1556407

9. Balcilar, M., Gupta, R., Lee, C. C., \& Olasehinde-Williams, G. (2018). The synergistic effect of insurance and banking sector activities on economic growth in Africa. Economic Systems, 42(4), 637-648. https://doi.org/10.1016/j. ecosys.2018.08.002

10. Bapna, R., Langer, N., Mehra, A., Gopal, R., \& Gupta, A. (2013). Human capital investments and employee performance: an analysis of IT services industry. Management Science, 59(3), 641-658. https://doi.org/10.1287/ mnsc. 1120.1586

11. Barney, J. B. (1986) Organizational culture: can it be a source of sustained competitive advantage? Academy of Management Review, 11(3), 656-665. https://doi. org/10.2307/258317

12. Beck, T., Demirgüç-Kunt, A., \& Levine, R. (2007) Finance, inequality and the poor. Journal of Economic Growth, 12(1), 27-49. https://doi.org/10.1007/s10887007-9010-6

13. Becker, G. (1964). Human Capital. NY: University of Chicago press.

14. Becker, G. S. (2009). Human capital: A theoretical and empirical analysis, with special reference to education. NY: University of Chicago press.

15. Benevene, P., Kong, E., Lucchesi, M., \& Cortini, M. (2019). Intellectual capital management among Italian non-profit sociocooperatives. Journal of Workplace Learning, 31(1), 17-30. https://doi. org/10.1108/JWL-07-2018-0085
16. Benhabib, J., \& Spiegel, M. M. (2005). Human capital and technology diffusion. Handbook of economic growth, 1, 935-966. Retrieved from http://www.econ nyu.edu/user/benhabib/growthhandbook10.pdf

17. Bontis, N., \& Fitz-Enz, J. (2002) Intellectual capital ROI: causal map of human capital antecedents and consequents. Journal of Intellectual capital, 3(3), 223-247. https://doi. org/10.1108/14691930210435589

18. Bontis, N., Ciambottí, M., Palazzi, F., \& Sgro, F. (2018). Intellectual capital and financial performance in social cooperative enterprises. Journal of Intellectual Capital, 19(4), 712-731. https://doi. org/10.1108/JIC-03-2017-0049

19. Bontis, N., Dragonetti, N. C., Jacobsen, K., \& Roos, G. (1999). The knowledge toolbox: A review of the tools available to measure and manage intangible resources. European Management Journal, 17(4), 391-402. Retrieved from https://ideas.repec.org/a/eee/eurman/v17y1999i4p391-402.html

20. Bratianu, C. (2018). Intellectual capital research and practice: 7 myths and one golden rule. Management \& Marketing, 13(2), 859-879. https://doi.org/10.2478/ mmcks-2018-0010

21. Cai, D., Song, Q., Ma, S., Dong, Y., \& Xu, Q. (2018). The relationship between credit constraints and household entrepreneurship in China. International Review of Economics \& Finance, 58, 246258. https://doi.org/10.1016/j. iref.2018.03.024

22. Carletti, E., Senbet, L. W., Cull, R., Allen, F., Qian, J., \& Valenzuela, P. (2018). Improving Access to Banking: Evidence from Kenya (BAFFI CAREFIN Centre Research Paper No. 2018-104). Retrieved from https://papers.ssrn. $\mathrm{com} /$ sol3/papers.cfm?abstract_ $\mathrm{id}=3305047$

23. Chen, C. J., \& Huang, J. W. (2009). Strategic human resource practices and innovation performance - The 
mediating role of knowledge management capacity. Journal of Business Research, 62(1), 104114. https://doi.org/10.1016/j. jbusres.2007.11.016

24. Chen, J., Zhu, Z., \& Yuan Xie, H. (2004). Measuring intellectual capital: a new model and empirical study. Journal of Intellectual Capital, 5(1), 195-212. https://doi. org/10.1108/14691930410513003

25. Chen, M. C., Cheng, S. J., \& Hwang, Y. (2005). An empirical investigation of the relationship between intellectual capital and firms' market value and financial performance. Journal of Intellectual Capital, 6(2), 159-176. https://doi. org/10.1108/14691930510592771

26. Chicu, D., del Mar Pàmies, M. Ryan, G., \& Cross, C. (2019). Exploring the influence of the human factor on customer satisfaction in call centres. $B R Q$ Business Research Quarterly, 22(2), 83-95. https://doi.org/10.1016/j. brq.2018.08.004

27. Chiorazzo, V., Milani, C., \& Salvini, F. (2008). Income diversification and bank performance: Evidence from Italian banks. Journal of Financial Services Research, 33(3), 181-203. https://doi.org/10.1007/s10693008-0029-4

28. Chiu, C. L., \& Chen, Y. S. (2017) A web-scale experience to identify the component impacts of intellectual capital on corporate performance from perspective of multimedia data applications. International Journal of Applied Systemic Studies, 7(1-3), 138153. https://doi.org/10.1504/ IJASS.2017.088907

29. Clarke, T., \& Gholamshahi, S. (2018). Developing human capital for knowledge based economies. In T. Clarke, \& K. Lee (Eds.), Innovation in the Asia Pacific (pp. 247-270). Springer, Singapore. https://doi.org/10.1007/978-98110-5895-0_12

30. Colombo, M. G., \& Grilli, L. (2005). Founders' human capital and the growth of new technology-based firms: A competence-based view. Research
Policy, 34(6), 795-816. https://doi org/10.1016/j.respol.2005.03.010

31. Crook, T. R., Todd, S. Y., Combs, J. G., Woehr, D. J., \& Ketchen Jr, D. J. (2011). Does human capital matter? A meta-analysis of the relationship between human capital and firm performance. Journal of Applied Psychology, 96(3), 443. https://doi.org/10.1037/ a0022147

32. Dakhli, M., \& De Clercq, D. (2007). Human capital, social capital, and innovation: a multicountry study. Entrepreneurship \& Regional Development, 16(2), 107-128. https://doi.org/10.1080/0 8985620410001677835

33. Davenport, T., \& Prusak, L. (1998). Working Knowledge: How Organizations Manage What The Know. Harvard Business School Press, Boston, MA.

34. Dietrich, A., \& Wanzenried, G. (2014). The determinants of commercial banking profitability in low-, middle-, and high-income countries. The Quarterly Review of Economics and Finance, 54(3), 337-354. https://doi.org/10.1016/j.

35. Drucker, P. (1993). Post-Capitalist Society, New York: Harper Business. Retrieved from http:// pinguet.free.fr/drucker93.pdf

36. Edvinsson, L., \& Malone, M. S. (1997). Intellectual capital: The proven way to establish your company's real value by finding its hidden brainpower. Piatkus.

37. Eggoh, J., Houeninvo, H., \& Sossou, G. A. (2015). Education, health and economic growth in African countries. Journal of Economic Development, 40(1), 93111. Retrieved from http://www. jed.or.kr/full-text/40-1/4.pdf

38. Felício, J. A., Couto, E., \& Caiado, J. (2014). Human capital, social capital and organizational performance. Management Decision, 52(2), 350-364. https:// doi.org/10.1108/MD-04-20130260

39. Firer, S., \& Mitchell Williams, S. (2003). Intellectual capital and traditional measures of corporate performance.
Journal of Intellectual Capital, 4(3), 348-360. https://doi. org/10.1108/14691930310487806

40. Fleisher, B., Li, H., \& Zhao, M. Q. (2010). Human capital, economic growth, and regional inequality in China. Journal of Development Economics, 92(2), 215-231.

41. Foong, K., Yorston, R., \& Gratton, L. (2003). Human capital measurement and reporting: a British perspective. DTI.

42. Gabriel, A. S., Cheshin, A Moran, C. M., \& van Kleef, G. A. (2016). Enhancing emotional performance and customer service through human resources practices: A systems perspective. Human Resource Management Review, 26(1), 14-24. https://doi. org/10.1016/j.hrmr.2015.09.003

43. Gennaioli, N., La Porta, R., Lopezde-Silanes, F., \& Shleifer, A. (2013). Human capital and regional development. The Quarterly Journal of Economics, 128(1) 105-164. Retrieved from https:// ideas.repec.org/a/oup/qjecon/ v128y2013i1p105-164.html

44. Goksu, A., \& Goksu, G. G. (2015) A comparative analysis of higher education financing in different countries. Procedia Economics and Finance, 26, 1152-1158. Retrieved from https://core.ac.uk/download/ pdf/82823884.pdf

45. Gololo, I. A. (2018). Challenges of the Nigerian Banking Sector and the Way Forward. American Finance \& Banking Review, 3(1), 26-34. Retrieved from https:// www.cribfb.com/journal/index. php/amfbr/article/view/216

46. Hahn, F. R. (2009). A note on management efficiency and international banking. Some empirical panel evidence. Journal of Applied Economics, 12(1), 69-81. https://doi.org/10.1016/S15140326(09)60006-4

47. Halim, S. (2010). Statistical analysis on the intellectual capital statement. Journal of Intellectual Capital, 11(1), 61-73. https://doi. org/10.1108/14691931011013334

48. Hall, R. (1992). The strategic analysis of intangible resources. Strategic Management Journal, 
13(2), 135-144. https://doi. org/10.1002/smj.4250130205

49. Han, Jin., Han, Jia., \& Brass, D. J. (2014) Human capital diversity in the creation of social capital for team creativity. Journal of Organizational Behavior, 35(1), 54-71. https://doi.org/10.1002/ job. 1853

50. Hannan, M. T., \& Freeman, J. (1984). Structural inertia and organizational change. American Sociological Review, 49(2), 149-164. Retrieved from https://www.jstor. org/stable/2095567

51. Harris, D., \& Helfat, C. (1997). Specificity of CEO human capital and compensation. Strategic Management Journal, 18(11), 895-920. https://doi. org/10.1002/(SICI)10970266(199712)18:11<895::AIDSMJ931>3.0.CO;2-R

52. Hatch, N. W., \& Dyer, J. H. (2004). Human capital and learning as a source of sustainable competitive advantage. Strategic Management Journal, 25(12), 1155-1178. https:// doi.org/10.1002/smj.421

53. Hitt, M. A., Bierman, L., Shimizu, K., \& Kochhar, R. (2001). Direct and moderating effects of human capital on strategy and performance in professional service firms: A resourcebased perspective. Academy of Management journal, 44(1), 13-28. https://doi.org/10.5465/3069334

54. Ilaboya, O. J., \& Ohiokha, I. F. (2016). Firm age, size and profitability dynamics: a test of learning by doing and structural inertia hypotheses. Business and Management Research, 5(1), 2939. https://doi.org/10,5430/bmr. v5n1p29

55. Itami, H., \& Roehl, T. W. (1987). Mobilizing Invisible Assets. Harvard University Press, Cambridge Mass.

56. Kasekende, E., \& Nikolaidou, E. (2018). Mobile Money and Money Demand in Kenya (Discussion Paper Series No. 2018-11). School of Economics, University of Cape Town. Retrieved from https:// ideas.repec.org/p/ctn/dpaper/2018-11.html
57. Khalique, M., Bontis, N., Nassir bin Shaari, J. A., \& Md. Isa, A. H. (2015). Intellectual capital in small and medium enterprises in Pakistan. Journal of Intellectual Capital, 16(1), 224-238. https://doi org/10.1108/JIC-01-2014-0014

58. Khan, S. J. M., \& Anuar, A. R. (2018). Access to Finance: Exploring Barriers to Entrepreneurship Development in SMEs. In Global Entrepreneurship and New Venture Creation in the Sharing Economy (pp. 92-111). IGI Global.

59. Kor, Y. Y., \& Mahoney, J. T. (2005). How dynamics, management, and governance of resource deployments influence firm level performance. Strategic Management Journal, 26(5), 489-496. https://doi.org/10.1002/ smj.459

60. Link, A.N. \& Siegel, D.S. (2007) Innovation, entrepreneurship, and technological change. Oxford: Oxford University Press.

61. Lu, C. C., \& Hsu, H. J. (2018). Exploring the Relationship between Organizational Capital and Service Innovation Behavior. International Journal for Innovation Education and Research, 6(12), 1-10. Retrieved from https://www.researchgate.net/ publication/330148463_Exploring_the_Relationship_between Organizational_Capital_and_Service_Innovation_Behavior

62. Maditinos, D., Chatzoudes, D., Tsairidis, C., \& Theriou, G. (2011). The impact of intellectual capital on firms' market value and financial performance. Journal of Intellectual Capital, 12(1), 132-151. https://doi. org/10.1108/14691931111097944

63. Mahdi, O. R., Nassar, I. A., \& Almsafir, M. K. (2019). Knowledge management processes and sustainable competitive advantage: An empirical examination in private universities. Journal of Business Research, 94, 320 334. https://doi.org/10.1016/j. jbusres.2018.02.013

64. Martin, B. C., McNally, J. J., \& Kay, M. J. (2013). Examining the formation of human capital in entrepreneurship: A metaanalysis of entrepreneurship education outcomes. Journal of Business Venturing, 28(2), 211-224. https://doi.org/10.1016/j.jbusvent.2012.03.002

65. McDowell, W. C., Peake, W O., Coder, L., \& Harris, M. L (2018). Building small firm performance through intellectual capital development: Exploring innovation as the "black box". Journal of Business Research, 88, 321-327. https://doi.org/10.1016/j. jbusres.2018.01.025

66. Megna, P., \& Mueller, D. C. (1991). Profit rates and intangible capital. The Review of Economics and Statistics, 73(4), 632-642. Retrieved from https://ideas. repec.org/a/tpr/restat/v73y1991i4p632-42.html

67. Muthinja, M. M., \& Chipeta, C. (2018). What drives financial innovations in Kenya's commercial banks? An empirical study on firm and macro-level drivers of branchless banking. Journal of African Business, 19(3), 385-408. https://doi.org/10.1080/15228916. 2017.1405705

68. Noe, R. A., Hollenbeck, J. R., Gerhart, B., \& Wright, P. M. (2017). Human resource management: Gaining a competitive advantage. NY: McGraw-Hill Education.

69. Noorbakhsh, F., Paloni, A., \& Youssef, A. (2001). Human capital and FDI inflows to developing countries: New empirical evidence. World Development, 29(9), 15931610. https://doi.org/10.1016/ S0305-750X(01)00054-7

70. Pelinescu, E. (2015). The impact of human capital on economic growth. Procedia Economics and Finance, 22, 184-190. https://doi.org/10.1016/S22125671(15)00258-0

71. Penrose, E., \& Penrose, E. T. (2009). The Theory of the Growth of the Firm. Oxford university press.

72. Peteraf, M. A. (1993). The cornerstones of competitive advantage: A resource-based view. Strategic Management Journal, 
14(3), 179-191. Retrieved from https://josephmahoney.web.illinois.edu/BA545_Fall\%202019/ Peteraf\%20(1993).pdf

73. Psillaki, M., \& Mamatzakis, E. (2017). What drives bank performance in transitions economies? The impact of reforms and regulations. Research in International Business and Finance, 39, 578-594. https://doi. org/10.1016/j.ribaf.2016.09.010

74. Pucar, S. (2012). The influence of intellectual capital on export performance. Journal of Intellectual Capital, 13(2), 248-261. https://doi. org/10.1108/14691931211225715

75. Pulic, A. (2000). MVA and $V A I C^{\text {mi }}$ Analysis of Randomly Selected Companies from FTSE 250. Austrian Intellectual Capital Research Center, Graz, London.

76. Reichenberg, M., \& Andreassen, R. (2018). Comparing Swedish and Norwegian teachers' professional development: How human capital and social capital factor into teachers' reading habits. Reading Psychology, 39(5), 442-467. https:// doi.org/10.1080/02702711.2018.1 464530

77. Reinartz, W., Krafft, M., \& Hoyer, W. D. (2004). The customer relationship management process: Its measurement and impact on performance. Journal of Marketing Research, 41(3), 293305. https://doi.org/10.1509\%2Fjm kr.41.3.293.35991

78. Sahari, S., Nichol, E. O., \& Yusof, S. M. (2019). Stakeholders' Expectations on Human Capital Disclosure vs. Corporate Reporting Practice in Malaysia. International Business Research, 12(1), 148-155. Retrieved from https://ideas.repec.org/a/ibn/ ibrjnl/v12y2019ilp148-155.html

Sardo, F., Serrasqueiro, Z., \& Alves, H. (2018). On the relationship between intellectual capital and financial performance: A panel data analysis on SME hotels. International Journal of Hospitality Management, 75, 67-74. https://doi.org/10.1016/j. ijhm.2018.03.001
80. Schultz, T. W. (1961). Investment in human capital. American Economic Review, 51(1), 1-17. Retrieved from https://www.jstor. org/stable/1818907

81. Seleim, A., Ashour, A., \& Bontis, N. (2007). Human capital and organizational performance: a study of Egyptian software companies. Management Decision, 45(4), 789-801. https://doi. org $/ 10.1108 / 00251740710746033$

82. Shivdas, A., \& Ray, S. (2017). Resource utilization by pharmaceutical companies in India: Emphasis on R\&D, labor and capital. In 2017 International Conference on Data Management, Analytics and Innovation (ICDMAI) (pp. 19-23). IEEE

83. Shrader, R., \& Siegel, D. S. (2007). Assessing the relationship between human capital and firm performance: Evidence from technology-based new ventures. Entrepreneurship Theory and Practice, 31(6), 893-908. https://doi.org/10.1111/j.15406520.2007.00206.x

84. Sikod, F., \& Baye, M. (2015). Microfinance Access and Poverty Reduction in Cameroon. In $\mathrm{La}$ microfinance en Afrique centrale: Le défi des exclus (pp. 253-284). Retrieved from https://idl-bncidrc.dspacedirect.org/bitstream/ handle/10625/54092/IDL-54092. pdf? sequence $=1$ \#page $=282$

85. Smriti, N., \& Das, N. (2017). Impact of intellectual capital on business performance: evidence from Indian pharmaceutical sector. Polish Journal of Management Studies, 15(1), 1-18. Retrieved from http://yadda.icm. edu.pl/yadda/element/bwmeta1. element.baztech-eae14a48-24c54e77-9509-4704bac023ab

86. Srivastava, K. B. (2001). Intellectual Capital Development and Management of Knowledge in Knowledge Based Economy. Indian Journal of Industrial Relations, 36(3), 355-362. Retrieved from https://www.jstor. org/stable/27767730

87. Ståhle, P., Ståhle, S., \& Aho, S . (2011). Value added intellectual coefficient (VAIC): a critical analysis. Journal of Intellectual Capital, 12(4), 531-551. https://doi. org/10.1108/14691931111181715

88. Stewart, T. A. (1997). Intellectual Capital. London: Nicholas Brealey.

89. Sufian, F., \& Chong, R. R. (2008). Determinants of bank profitability in a developing economy: empirical evidence from the Philippines. Asian Academy of Management Journal of Accounting \& Finance, 4(2), 91-112. Retrieved from https://pdfs.semanticscholar. org/6883/7ac6624c85d1183d392 $4 \mathrm{db} 342 \mathrm{~d} 1 \mathrm{dcf} 4 \mathrm{~d} 81 \mathrm{c} 9 . \mathrm{pdf}$ ? ga $=2$. 98034710.886887132.1587984095-2100778558.1584432533

90. Sufian, F., \& Habibullah, M. S. (2009). Determinants of bank profitability in a developing economy: Empirical evidence from Bangladesh. Journal of Business Economics and Management, 10(3), 207-217. https://doi.org/10.3846/16111699.2009.10.207-217

91. Sun, S. T., \& Yannelis, C. (2016). Credit constraints and demand for higher education: Evidence from financial deregulation. Review of Economics and Statistics, 98(1), 12-24. Retrieved from https:// ideas.repec.org/a/tpr/restat/v98y2016ilp12-24.html

92. Sveiby, K. E. (1997). The new organizational wealth: Managing \& measuring knowledge-based assets. Berrett-Koehler Publishers.

93. Toms, S., Wilson, N., \& Wright, M. (2019). Innovation, intermediation, and the nature of entrepreneurship: A historical perspective. Strategic Entrepreneurship Journal, 14(1). https://doi.org/10.1002/sej.1310

94. Tongurai, J., \& Vithessonthi, C. (2018). The impact of the banking sector on economic structure and growth. International Review of Financial Analysis, 56, 193207. https://doi.org/10.1016/j. irfa.2018.01.002

95. Ulrich, D., \& Kryscynski, D. (2015). Winning in challenging markets requires stronger attention to human capital. LSE Business Review. Retrieved 
from http://eprints.lse.ac.uk/id/ eprint/73018

96. Wan, G., \& Zhang, Y. (2018). The direct and indirect effects of infrastructure on firm productivity: Evidence from Chinese manufacturing. China Economic Review, 49, 143-153. https://doi.org/10.1016/j.chieco.2017.04.010

97. Wang, W. Y., \& Chang, C. (2005). Intellectual capital and performance in causal models:
Evidence from the information technology industry in Taiwan. Journal of Intellectual Capital, 6(2), 222-236. https://doi. org/10.1108/14691930510592816

98. Wernerfelt, B. (1984). A resourcebased view of the firm. Strategic Management Journal, 5(2), 171180. https://doi.org/10.1002/ smj.4250050207

99. Wright, P. M., McCormick, B., Sherman, W. S., \& McMahan, G. C. (1999). The role of human resource practices in petro- chemical refinery performance. International Journal of Human Resource Management, 10(4), 551-571. https://doi. org/10.1080/095851999340260

100. Young, C.-S., Su, H.-Y., Fang, S.-C., \& Fang, S.-R. (2009) Cross-country comparison of intellectual capital performance of commercial banks in Asian economies. The Service Industries Journal, 29(11), 1565-1579. https://doi. org/10.1080/02642060902793284 